\title{
Études/Inuit/Studies
}

\section{Bretons, Basques, and Inuit in Labrador and northern Newfoundland: The control of maritime resources in the 16th and 17th centuries \\ Bretons, Basques et Inuit au Labrador et au nord de Terre-Neuve: le contrôle des ressources maritimes aux XVI ${ }^{\mathbf{e}}$ et $\mathrm{XVII}^{\mathrm{e}}$ siècles}

\author{
Peter E. Pope
}

Volume 39, numéro 1, 2015

Les Inuit au Labrador méridional

The Inuit in southern Labrador

URI : https://id.erudit.org/iderudit/1036076ar

DOI : https://doi.org/10.7202/1036076ar

Aller au sommaire du numéro

Éditeur(s)

Association Inuksiutiit Katimajiit Inc.

Centre interuniversitaire d'études et de recherches autochtones (CIÉRA)

ISSN

0701-1008 (imprimé)

1708-5268 (numérique)

Découvrir la revue

Citer cet article

Pope, P. E. (2015). Bretons, Basques, and Inuit in Labrador and northern Newfoundland: The control of maritime resources in the 16th and 17th centuries. Études/Inuit/Studies, 39(1), 15-36. https://doi.org/10.7202/1036076ar

\section{Résumé de l'article}

Sur la côte atlantique du Canada, les premiers contacts entre Européens et Inuit soulèvent un problème complexe de l'ethnohistoire de l'exploitation des ressources. $\mathrm{Au} \mathrm{XVI}{ }^{\mathrm{e}}$ siècle, les équipages bretons, normands et basques ont développé une industrie saisonnière de pêche et de salaison de la morue sur les côtes du nord de Terre-Neuve et du sud du Labrador, autour de la même période où les Inuit se déplaçaient vers le sud, le long de la côte du Labrador. Les Basques exploitaient également le détroit de Belle Isle, entre Terre-Neuve et le Labrador, pour chasser la baleine à partir du rivage. À un certain moment, avant 1620, les Européens paraissent s'être retirés du Labrador jusque vers 1680, époque où les marchands canadiens de Québec ont commencé à exploiter les saumons et les phoques du détroit, tandis que les équipages saisonniers français effectuaient à nouveau des poussées vers le nord à partir de Terre-Neuve. Le retrait des Européens du Labrador coïncide dans une large mesure avec une longue guérilla menée par les Inuit contre les pêcheurs bretons et basques qui exploitaient la Grande Péninsule du Nord de Terre-Neuve. La coïncidence chronologique laisse penser que le déplacement des Inuit vers le sud du Labrador à la fin du XVI ${ }^{\mathrm{e}}$ siècle pourrait bien avoir incité les Européens à éviter cette côte durant la plus grande partie du $\mathrm{XVII}^{\mathrm{e}}$ siècle. On peut contextualiser les attitudes des Français envers les Inuit du Labrador en les comparant avec des façons contemporaines d'envisager les relations entre Européens et Inuit dans d'autres lieux. Il est plus difficile de cerner les attitudes des Inuit envers les Européens, mais le fait d'admettre qu'ils luttaient pour avoir accès aux ressources constitue une avancée pour reconnaître l'agir des Inuit dans l'histoire. 


\title{
Bretons, Basques, and Inuit in Labrador and northern Newfoundland: The control of maritime resources in the 16 th and 17 th centuries
}

\author{
Peter E. Pope*
}

Résumé: Bretons, Basques et Inuit au Labrador et au nord de Terre-Neuve: le contrôle des ressources maritimes aux $\mathrm{XVI}^{\mathrm{e}}$ et $\mathrm{XVII}{ }^{\mathrm{e}}$ siècles

Sur la côte atlantique du Canada, les premiers contacts entre Européens et Inuit soulèvent un problème complexe de l'ethnohistoire de l'exploitation des ressources. Au XVI siècle, les équipages bretons, normands et basques ont développé une industrie saisonnière de pêche et de salaison de la morue sur les côtes du nord de Terre-Neuve et du sud du Labrador, autour de la même période où les Inuit se déplaçaient vers le sud, le long de la côte du Labrador. Les Basques exploitaient également le détroit de Belle Isle, entre Terre-Neuve et le Labrador, pour chasser la baleine à partir du rivage. À un certain moment, avant 1620, les Européens paraissent s'être retirés du Labrador jusque vers 1680, époque où les marchands canadiens de Québec ont commencé à exploiter les saumons et les phoques du détroit, tandis que les équipages saisonniers français effectuaient à nouveau des poussées vers le nord à partir de Terre-Neuve. Le retrait des Européens du Labrador coïncide dans une large mesure avec une longue guérilla menée par les Inuit contre les pêcheurs bretons et basques qui exploitaient la Grande Péninsule du Nord de Terre-Neuve. La coïncidence chronologique laisse penser que le déplacement des Inuit vers le sud du Labrador à la fin du XVI ${ }^{\mathrm{e}}$ siècle pourrait bien avoir incité les Européens à éviter cette côte durant la plus grande partie du XVII ${ }^{\mathrm{e}}$ siècle. On peut contextualiser les attitudes des Français envers les Inuit du Labrador en les comparant avec des façons contemporaines d'envisager les relations entre Européens et Inuit dans d'autres lieux. Il est plus difficile de cerner les attitudes des Inuit envers les Européens, mais le fait d'admettre qu'ils luttaient pour avoir accès aux ressources constitue une avancée pour reconnaître l'agir des Inuit dans l'histoire.

Abstract: Bretons, Basques, and Inuit in Labrador and northern Newfoundland: The control of maritime resources in the 16 th and 17 th centuries

Early Euro-Inuit contacts in Atlantic Canada raise a complex issue in the ethnohistory of resource exploitation. In the 16th century, Breton, Norman, and Basque crews developed a seasonal salt-cod fishery on the coasts of northern Newfoundland and southern Labrador, in about the same period that the Inuit moved southwards along the Labrador coast. The Basques also exploited the Strait of Belle Isle, between Newfoundland and Labrador, for shore-based whaling. Sometime before 1620, Europeans then appear to have withdrawn from Labrador until

* Department of Archaeology, Memorial University of Newfoundland, St. John's, Newfoundland and Labrador A1C 5S7, Canada. ppope@mun.ca 
about 1680, when Canadian merchants based in Quebec began to exploit the Strait for salmon and seals, while French migratory crews edged northwards again from Newfoundland. European withdrawal from Labrador largely coincided with a long-running guerrilla war, waged by the Inuit against Breton and Basque fishermen exploiting Newfoundland's Great Northern Peninsula. The chronological coincidence suggests that the movement of Inuit into southern Labrador by the end of the 16th century may well have motivated Europeans to avoid this coast through much of the 17 th century. French attitudes to the Labrador Inuit can be contextualized by comparison with contemporary understandings of Euro-Inuit relations elsewhere. Inuit attitudes to Europeans are harder to assess but recognition of their struggle for access to resources is a step towards an appreciation of historical Inuit agency.

\section{Introduction}

In November 1687, the 220-ton Breton ship Sainte Claire, returned home to Saint Malo. In this period, the economy of northern Brittany was strongly oriented to the migratory transatlantic salt cod fishery, particularly on the Petit Nord, the Atlantic coast of Newfoundland's Great Northern Peninsula. The Sainte Claire had been on the Petit Nord but had not been fishing. On November 8, the ship's master, Thomas Huriau, filed a report on the voyage to the local Admiralty (Huriau 1687). As he put it, they had gone to "terre neufve [...] en guerre contre les sauvages", that is, armed against the savages - and he had some bad news to report. He left one François Hunas, a soldier from his ship, as a sentinel on Belle Isle in the strait of that name, but when the Sainte Claire returned, they found him with his throat slit: "esgorgé par les Sauvages." From the late 16th century, through the 17th, and well into the 18th, similar accounts report organized conflict between French fishing crews from Brittany and the Basque Country with Aboriginal people travelling in skin boats along the coasts of southern Labrador and northern Newfoundland (La Morandière 1962: 385-390; Martijn 1980, 2009; Mitchell 2013; Stopp 2002). These were the Labrador Inuit - close cousins of the NeoEskimo Thule people who had reoccupied Greenland in the late Middle Ages. ${ }^{1}$

The point of this paper is to draw attention to the guerrilla war that flared in northern Newfoundland and in southern Labrador for almost two centuries, roughly until the British conquest of 1763. "Guerrilla war" is Charles Martijn's (1980: 108) apt description. The phrase captures nicely the asymmetry of armed conflict between an organized merchant interest within a state society, like early modern France, and a mobile band society, like the Labrador Inuit before the Christianization, sedentism, and intermarriage of the later 18th century. These pages are not intended as a contribution to the lively debate about the chronological or geographical limits of Inuit presence in this region. Instead, one plausible current interpretation of Inuit territorial expansion is taken for granted, with the intention of working out the implications for the Europeans who also exploited the area. From this perspective, it looks like war with the Inuit kept

1 For another view, see Taylor (1980).

16/P.E. POPE 
the French off the Labrador coast through much of the 17 th century. ${ }^{2}$ But why were mariners from France and the Inuit at war?

\section{A brief ethnohistory}

Amerindian peoples, perhaps descended from the ancient Maritime Archaic, occupied both Newfoundland and southern Labrador in the late pre-contact period. In Newfoundland these were the ancestors of the historic Beothuk, now culturally extinct (Rankin 2008). A related Algonkian people, the Innu (Montagnais) occupied southern Labrador and survive today. These Amerindians exploited the resources of the Strait of Belle Isle, between Labrador and Newfoundland. In the 16th century, the picture became more complicated, with the arrival of two new groups: from the other side of the Atlantic Ocean, the Europeans and, from the north, the Inuit.

Europeans had already visited the Strait of Belle Isle in medieval times. The Norse site at L'Anse aux Meadows, Newfoundland, is probably the remains of Leifr Eiriksson (Leif Erikson)'s exploration camp of ca. AD 1000 (Wallace 2009). Although Vinland was largely forgotten, a geographic memory of the Norse route to the west may have echoed into early modern times: Newfoundland's northern tip, which faces the Strait, is the only part of the North American coast that we can securely associate with Zuan Chabotto (John Cabot)'s exploratory voyage of 1497 (Pope 2000). The Strait of Belle Isle is also one of the areas first exploited in the early decades of the 16th century by Breton, Norman, and Basque fishing crews, who (with the Portuguese) were among the first Europeans to follow up Cabot's discovery of new and immensely productive fishing grounds (Pope 2015a).

By the 1540s, merchants in the Spanish and French Basque provinces had also begun to mount whaling voyages to this region, which they called La Gran Baya (Barkham 1982; Proulx 2007). For about 50 years, dozens of ships brought thousands of men from Viscaya, Guipuzcoa, and Labourd to the south Labrador coast, where they hunted bowhead whales and rendered them into oil at prominent shore-stations. This has become one of the most engaging chapters in early Canadian history, for the topic blends elements that have broad popular appeal: whales, which are large intelligent mammals, hunted close to extinction; a forgotten period or, at least, one not well remembered; and the Basques themselves, a people often considered mysterious, an identity deriving from their non-Indo-European language and uncertain provenance. The archaeological visibility of whaling stations, both literally and culturally, has meant that in the popular imagination Basque whaling was the primary European presence in Atlantic Canada in the 16th century, although in fact the early modern

2 "Labrador" is used here to mean the coast now part of the province of Newfoundland and Labrador. The term "Quebec North Shore" is used for the adjacent coast to the west, which forms the southern limit of the Quebec-Labrador Peninsula. For simplicity, 17th-century Basque fishermen are treated here as subjects of France and characterized as "French" fishermen. In fact, some Spanish Basque fishermen and perharps even ships may have continued to exploit Atlantic Canadian waters in this period (Brad Loewen, pers comm.). 
migratory cod fishery was not only an earlier industry but also a significantly larger one (Loewen and Delmas 2011, 2012; Turgeon 1997: 11). Even at Red Bay, the largest and most celebrated Basque whaling station on the Labrador coast, the deposits of cod bone are truly impressive (Stevens et al. 2007).

Contemporary references indicate that Breton, Norman, and Basque crews were regularly setting up seasonal fishing rooms in southern Labrador and on the adjacent Quebec North Shore, at Pleasure Harbour, Chateau Bay, Red Bay, Carroll's Cove, St. Modeste, L'Anse au Loup, Blanc Sablon, Middle Bay, and Bonne Esperance (Figure 1) (La Morandière 1962: 705-707, Mannion and Barkham 1988). Sixteenth-century fishers also developed seasonal stations on the Petit Nord, the Atlantic coast of Newfoundland's Great Northern Peninsula, notably at La Scie, Fleur de Lys, Orange (now Great Harbour Deep), Cap Rouge, Groais Island, St. Julien, Croque, Fichot Island, La Crémallière, Griquet, Quirpon, and Cap Dégrat (Cook 1993: 159-168; Hoyarsabal 1579; La Morandière 1962: 226-228; La Roncière 1904). Although the Basques, in particular, would operate fishing stations on Newfoundland's west coast, particularly at Port au Choix and Ferrolle, these were later developments (Barkham 1989).

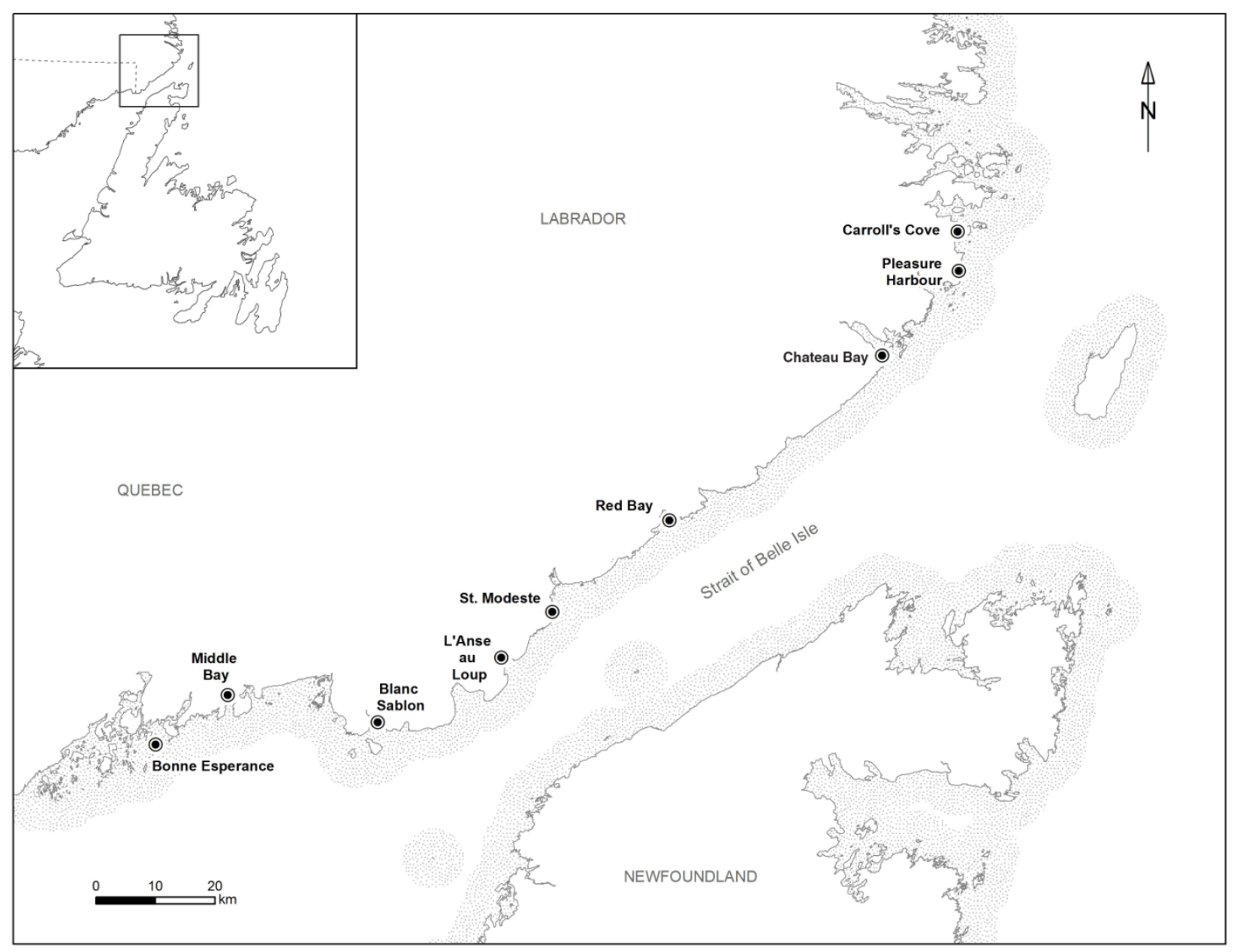

Figure 1. Shore stations in southern Labrador used by European fishers and whalers in the 16th century. Map by Bryn Tapper.

18/P.E. POPE 
A recent revision of Thule radiocarbon dates by Robert McGhee $(2000,2009)$ suggests that the ancestors of the historical Inuit did not reach southern Labrador until the second half of the 16th century, when European fishing crews had already established seasonal stations there. The Thule people were seal hunters, who had a keen appreciation of the advantages of iron tools. In Alaska, where this culture originated, their iron likely came from Siberia. The rapid spread of the Thule from Alaska across the Arctic is now dated to the mid-13th century - which is, in fact, just when they were first recorded by the Greenland Norse. Finding a reliable source of iron was likely the motivation for migration and for their contacts with the Norse. After 1500, they abandoned the High Arctic and began to occupy the southeast Arctic, including Labrador.

The earliest Inuit house sites identified on the Labrador coast date from about 1500 in the north and from about 1650 on the mid coast, around Sandwich Bay (Ramsden and Rankin 2013). They became known in southern Labrador about 1580, as seasonal visitors (Martijn 1980: 105). One of the reasons they were there was to obtain iron, which they knew they could get from Europeans. Peter Ramsden and Lisa Rankin put it succinctly: "while Europeans came to Labrador in search of new resources, the Inuit came to Labrador in search of new Europeans" (ibid.: 307). Marianne Stopp (2002: 83, 95) has argued that Inuit expansion southwards is better explained as an expression of subsistence needs rather than as a search for European iron. This may not have been, however, a relevant distinction for the Inuit, who had come to depend on iron tools for their subsistence. They could access iron and other European goods through face-toface trade, by scavenging at seasonal processing stations, or by attacking isolated crews. ${ }^{3}$ The archaeological record indicates that they must have used at least one of these strategies; the documentary record suggests that they used all of them, depending on the circumstances. To apply Kara Wolfe's (2013: 42-45) useful typology of contact, Inuit relations with Europeans were direct rather than indirect, but intermittent rather than ongoing and often confrontational, though increasingly cooperative, in the 18th century.

\section{Early Euro-Aboriginal contact in Atlantic Canada}

From the earliest days of the transatlantic extractive industries in Atlantic Canada, Europeans interacted with Aboriginal peoples. The late medieval/early modern practice of portage reduced wage costs to ship owners by giving mariners the right to carry a little cargo on their own account. In the 16th and 17th centuries, French fishers in the Gulf of Saint Lawrence frequently used this right to trade for furs with Amerindian peoples, supplying European goods such as knives, axes, or cloth (Pope 1995). About 1560 , the Normans began to commercialize this trade but, by 1600 , it was the Basques who dominated the Gulf commercially - a dominance reflected in the widespread archaeological survival of Basque trade goods, including axes and copper kettles

3 Scavenging means to search for and collect recyclable waste. To read a negative connotation into the word is to impose a class perspective in favour of waste. 
(Turgeon 1998). Another indication of close Basque interaction with Aboriginal peoples of the Gulf of Saint Lawrence was the development of pidgin trade languages (Bakker 1989, 1991). In the 16th century, European whalers and fishing crews in the Strait of Belle Isle generally maintained friendly relations with Amerindian peoples, including notably the Innu (Montagnais) - a situation that may explain the archaeological traces of an Amerindian presence during the Basque occupation of Red Bay (Barkham 1980; Tuck 1989; Turgeon 1998).

European relations with the Labrador Inuit took a different course. Development of a Basque-Inuit trade pidgin and Richard Hakluyt's hopes in 1584 for trade with the people he called "Esquimawes of the Graunde Bay" suggest that non-aggressive exchanges did occur between Europeans and Inuit in the 16th century (Bakker 1991; Hakluyt 1935[1584]: 269). Yet historical indications of friendly relations are rare, and there are many strong indications of conflict (Martijn 1980: 107-110; Mitchell 2013). Jean Alphonse, a cosmopolitan mariner who worked as a pilot on Roberval's expedition up the Saint Lawrence in the 1540s, called northern Aboriginal people "belliqueux" or warlike (in Martijn 1980: 106). In 1586, the English explorer John Davis lost five men to the Inuit in Labrador (Janes 1979[c. 1586]). French observers of the early 17 th century warn of the Aboriginal people of the northern coasts. Marc Lescarbot (1907[1618]: 245) observed that "towards the north there is a ferocious nation which wages perpetual war against our mariners as they pursue their fishery." 4 The early 17th-century Basque historian Lope de Isasti (in Barkham 1980: 54) distinguished two Aboriginal groups in the Strait of Belle Isle. On the one hand, the people he called montañeses learned enough Basque to "talk and associate with our men and help to prepare the fish on shore in exchange for a little bread, biscuit and cider that they do not have over there." 5 On the other hand, the people he called esquimaos were hostile to European fishermen and attacked them with bows and arrows. Samuel de Champlain summed up contemporary European stereotypes of the Inuit:

The savages of the north coast are very malicious, and attack the fishermen, who in selfdefence arm small vessels to protect the boats which put to sea to fish for cod. It has been impossible to make peace with them. For the most part they are small men, with very ugly faces and deep-set eyes, wicked and treacherous in the highest degree. They clothe themselves in the skins of seals which they make into garments very skillfully. Their boats are of leather; and in them they go prowling about and making war. They have killed a number of the St. Malo men, who had previously paid them back in double measure (Champlain 1933[1632]: 168-169). ${ }^{6}$

What a world of conflict is conjured up by Champlain's throwaway line: "previously paid them back"! We hear less in European sources about such vengeance than we do of Inuit violence; the documentary record of this conflict being effectively

\footnotetext{
$4 \quad$ All translations mine, unless otherwise noted.

5 Barkham's translation.

6 LeSueur's translation.
} 
univocal. We do learn that in 1566 French fishers killed an Inuit hunter, presumably in Labrador, taking his wife and child to Europe, where they ended up as a kind of circus exhibit (Sturtevant 1980). The 18th-century naval officer Antoine Thévenard regarded 1588 as the beginning of Franco-Aboriginal conflict on the Petit Nord, when a Breton crew killed the leader of an Inuit party at Quirpon (Thévenard 1800). Biard, Lescarbot, Champlain, and Father Le Clercq interpreted this incident or one like it, in lurid detail, as the trigger for Franco-Inuit hostility-although Le Clercq tells the tale about the Innu-Montagnais petits Eskimaux of the Quebec North Shore, rather than the Inuit grands Eskimaux of the Strait of Belle Isle (Biard 1616: 33; Champlain 1933[1632]: 169; LeClercq 1999[1691]: 266-268; Lescarbot 1907[1618]: 245; cf. Martijn 1980: 111-118). ${ }^{7}$ The fishermen involved are sometimes supposed to have been Basque and are sometimes Breton or generically French. Revenge for specific incidents of theft or of murder may have been a factor in prolonging hostilities but the very context of the Euro-Inuit encounter was not, unfortunately, conducive to friendly relations. Le Clercq (1999[1691]: 512) observed that the Basques fishing at Brador, near Blanc Sablon, ran great risks "because of the implacable war" with the Inuit. The fact that the Inuit did not arrive in southern Labrador until the second half of the 16th century may have something to do with these tensions. In effect, both the Europeans and the Inuit were then seasonal newcomers to the Strait of Belle Isle: both eager to find solid footing; both willing to push others aside.

On the basis of current historical and archaeological data, it would appear that by 1600 the Inuit were exploiting southern Labrador and northern Newfoundland, at least in summer and fall, and that they used these voyages to obtain European iron. By 1640, some Inuit families were overwintering as far south as Mingan on the Saint Lawrence North Shore (Fitzhugh et al. 2012; Martijn 1980: 106). This is not, however, evidence that they occupied southern Labrador year-round in the 16th century. ${ }^{8}$ An archaeological comparison of iron from a Petit Nord fishing room at Cap Rouge with iron from Inuit wintering sites at the mouth of Sandwich Bay suggests that 17th-century Labrador Inuit were still using iron nails, most likely collected from European fishing stations, to fashion into endblades, scrapers, and other tools (Wolfe 2013). The Beothuk of the Island of Newfoundland obtained iron in a similar way (Pastore 1987). Whereas the latter could access seasonally abandoned fishing stations in the off-season, the Inuit were often faced with the challenge of collecting iron from occupied stations. An efficient alternative was to pick off an isolated boat crew. This tactic could yield knives, seines, clothing, and European shallops, all of which the Inuit also coveted, particularly the latter (cf. Lanteigne 2014). Both scenarios appear to have played out repeatedly. When Breton or Basque captains recorded the deaths of three fishermen at a time, we can suspect the loss of a boat and its crew. Whether or not it was the Inuit intent, their presence near European stations was feared by crews, and even scavenging expeditions were regarded as a kind of harassment.

7 The several accounts of this incident both echo and contradict each other. See note 5 in Martijn (1980: 123).

8

BRETONS, BASQUES, AND.../21 
Perhaps not surprisingly, the extant documentary and archaeological evidence suggests that European fishers and whalers generally abandoned southern Labrador by about 1620. So rare is evidence for European presence in the following period that some researchers have erroneously assumed that European fishers did not exploit Labrador until the late 17th century (Kaplan 1985: 57-58). In a period for which shipping statistics are tenuous at best, it is always difficult to reconstruct transatlantic industrial activity - but we have scraps of evidence for earlier and later presence, with little or none for the time in question. European goods are increasingly common at Labrador Inuit sites of this period - but this paradox could be explained by continued Inuit collecting at long-abandoned European sites and, perhaps more significantly, by the gradual extension of the Labrador Inuit seasonal procurement zone into northern Newfoundland.

Pending the publication of credible evidence of European activity in southern Labrador between 1620 and 1680, this paper adopts the working hypothesis that Europeans were generally absent. This interpretation raises two questions: why and with what result? When Augustin de Courtemanche set up a sealing station at Brador near Blanc Sablon, in 1705, the Innu (Montagnais) told him that the Basques used to fish there and "would probably still be [...] if it wasn't for the bad treatment they received at the hands of the Esquimaux" (Courtemanche 1927[c. 1705], cf. Martijn 1980: 109). Together with Spain's loss of the great Armada in 1588, declining whale stocks, and the discovery of alternate hunting grounds, interethnic tensions were at most one factor in the decline of European activity in the Strait of Belle Isle. What is more certain is that early in the 17th century, the Basques abandoned their Labrador stations, to concentrate on whaling off Spitzbergen, on the hunt for sea mammals in the Gulf of Saint Lawrence, and on the cod fishery along the south and west coasts of Newfoundland (Barkham 1989). The Bretons also withdrew from Labrador and concentrated on the Chapeau Rouge fishery on Newfoundland's south coast and on the Petit Nord fishery along the Atlantic coast of the Great Northern Peninsula (La Morandière 1962: 385-402, 703-716). By 1620, the way was clear for the Labrador Inuit to penetrate the Gulf of Saint Lawrence (Martijn 1980: 122).

\section{The Inuit war on the Petit Nord}

French crews fished Newfoundland's Petit Nord for about 400 years, roughly 1500 to 1900 . In the 17th century, some 10,000 to 12,000 fishermen from the various provinces of France arrived annually in Newfoundland to catch and salt cod; of these, 5,000 to 6,000 exploited the coast of the Petit Nord. Their visits were focused on relatively few fishing stations there-around 30 at that time (Figure 2). The practice of bringing fish back to fishing rooms for processing meant that relatively small shore stations could serve wider stretches of coast - as far as the crew of a fishing shallop could conveniently sail or row in a day. The combination of features that make a workable fishing room is actually rare: a safe place to moor or careen a ship, protected water for landing boats, proximity to reliable fishing grounds, accessible bait species, wood for stages and flakes, open areas for drying, and fresh water for the crew (Tapper 
2014). The most obvious landmarks of the shore-based salt-cod fishery were these fishing rooms - clustered in major protected harbours (Pope 2009). Breton and Norman crews traditionally used about 180 fishing rooms on the Petit Nord, a half dozen or so at most fishing stations. Quirpon, at the northern tip of Newfoundland, sheltered about eight rooms on several different islands. Croque and Cap Rouge Harbour, a day's sail to the south, each sheltered a similar number of rooms. A hundred men with dozens of boats might use each of these fishing rooms.

Over the centuries, the Petit Nord emerged as the heart of the French migratory fishery in Newfoundland. In the 17th century, the French gradually abandoned the east coast of Newfoundland, south of Bonavista, to the English. After 1713, French crews were banned from the island's south coast and exploited the northeast coast only intermittently - so French migratory crews concentrated increasingly on the Great Northern Peninsula, Bretons exploiting particularly the Petit Nord, the Atlantic coast of the region. Their ethnicity separated them from the Basque crews who were by then fishing at Port au Choix and a few other harbours on Newfoundland's west coast. So the Atlantic coast between La Scie in the south and Quirpon in the north was a distinct and coherent maritime cultural landscape, conceptualized in this way by the fishermen themselves (Pope 2015b). As early as 1640, the Parlement of Brittany published regulations for the cod fishery on the Petit Nord (Parlement de Bretagne 1640). Even earlier, the merchants of Saint Malo had already defined the region by organizing a defence of their fishery on this coast against Inuit attack from Labrador.

In 1610, Inuit ambushed and killed a number of Breton boat crews, at Grandois and Croque (Kirke 1639, cf. Howley 1915: 23). ${ }^{9}$ This led Saint Malo merchants, in the following year, to propose a levy on all Breton fishing ships going to the Petit Nord, the proceeds to be used to arm a vessel to protect the fishery (Du Bois Saint-Séverin 1877; La Morandière 1962: 386-397). Despite the resistance of some other Breton fishing ports, the Malouins continued in the 1630s and 1640s to press for contributions to their military effort against the Inuit. ${ }^{10}$ Finally, in 1647, Louis XV gave Saint Malo letters patent obliging ships fishing on the Petit Nord to support the Malouin armed escort vessel and authorizing it to carry 70 to 80 men, 6 pataches as patrol boats, plus the necessary arms (La Morandière 1962: 388). (A patache was a small decked vessel, useful for moving troops.) In 1669, a petition to the Commissaire de la Marine in Saint Malo referred to the patrol vessel as a normal feature of the Petit Nord fishery (Narp 1669 , cf. Pope 2015c). In 1687, as we have seen, the Sainte Claire acted as the patrol, carrying 72 men, 12 cannons, 80 muskets, and 40 pikes. The ship and a few men stayed in Croque at the Havre du Petit Maitre but her six pataches patrolled the coast "making war on the savages in order to forestall their incursions against the other vessels" (Huriau 1687). Records of the Petit Nord patrol vessel also survive from 1673, 1688, and 1689.

9 Kirke appears to have been confused about the date.

10 Opponents included the ports of Binic, Paimpol, and Bréhat. 


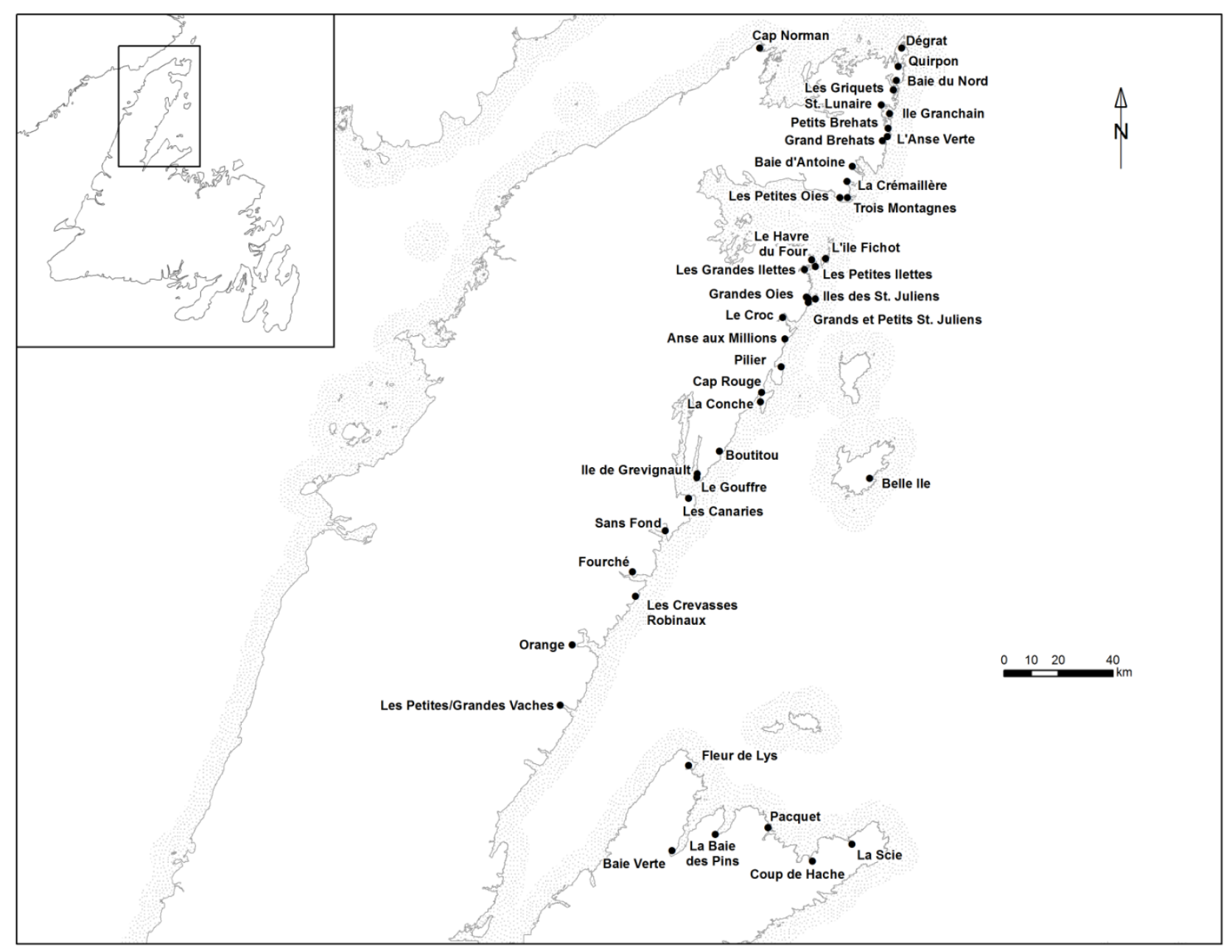

Figure 2. Breton fishing stations on Newfoundland's Petit Nord in the 17th century. Many of the northern stations, including Quirpon, Dégrat, Griquet, La Crémallière, Fichot, St. Julien, Le Croc (= Croque), Groais Island, Cap Rouge, Orange (Great Harbour Deep), Fleur de Lys, and La Scie were already being operated in the 16th century by Breton, Norman, and Basque crews. Map by Bryn Tapper.

It is hard to say exactly when Saint Malo abandoned the practice of annually sending a military force to the Petit Nord, but it was not before the war that broke out between France and Britain in 1689 and which was not really resolved until the Treaty of Utrecht in 1713. In 1693, an Inuit party in two shallops and six kayaks attacked two of the Saint Malo patrol boats in the Petit Nord harbour of Boutitou, running one patache aground and killing one of the French marines (La Morandière 1962: 389; Martijn 2009: 78). Fishers from France-including both Malouins on the Petit Nord and Basque crews fishing at Port au Choix on the west coast of Newfoundland-were still employing armed patrol boats, at the turn of the 18th century (Graydon 1910[1701]; Lahontan 1990[1703]). A British report of 1762 suggests that by midcentury French fishing ships were armed against Inuit attack and did not rely on a specially-commissioned escort (Graves 1762). ${ }^{11}$

11 I am indebted to Greg Mitchell for drawing my attention to this document. 
After 1713, the situation of both the French and the Inuit changed. The Petit Nord had become the centrepiece of the new diplomatically-defined French Shore, in northern Newfoundland (Hiller 1996). The French lost their fisheries elsewhere in Newfoundland and, for migratory transatlantic crews, southern Labrador was a promising alternative to the overcrowded Cape Breton or Gaspé fisheries (Brière 1990: 138-139). Meanwhile, the Inuit were gradually adapting to trading rather than raiding. The economics of raiding were, of course, inherently unstable, in the sense that Inuit methods for obtaining iron tended to drive away the very source they were exploiting. Trade, once it finally found a foothold, was more predictable and less costly in human terms for all concerned. Analysis of 18th-century Labrador Inuit assemblages suggests that they had begun to trade for manufactured iron goods. They still used European nails, but somewhat smaller ones, no longer for reworking but to build door frames and so on, in the European manner (Wolfe 2013). From the 1680s on, trade was facilitated by the return of Europeans and Euro-Americans to the Labrador coast. Not only were Breton and other French crews beginning to fish on the Labrador side of the Strait of Belle Isle again, but Quebec merchants also obtained land grants to establish permanent sealing and salmon stations in southern Labrador and on the Great Northern Peninsula in the 1690s and early 1700s (Jolliet 1944[1694]; Martijn and Dorais 2001; Trudel 1978, 1980).

Despite the slow development of Euro-Inuit commercial relations in the 18th century, both the Bretons on the Petit Nord and the Basques on Newfoundland's west coast still had to deal with occasional organized attacks by large Inuit war parties (Martijn 2009: 78-79; Stopp 2002: 81). The extensive evidence for 18th-century conflict in Labrador gives vivid indications of how the Inuit overcame European technical advantages in weaponry and suggests that they adopted a program of economic sabotage (e.g., Brouague 1923[1720], 1923[1729]; Crompton 2014). The precarious state of emerging trade is well indicated by the royal order forbidding French fishing masters to supply firearms to the Inuit (Louis XV 1734). Crew lists kept by the French Navy in Brest indicate that significant deadly Inuit attacks on Breton fishing crews continued: something like 29 fishermen died in this way between 1749 and 1753 (Lanteigne 2014). Admiral Thévenard (1800) thought deadly violence on the Petit Nord had persisted since 1588 into the time of his own service there, in the 1750s. Finally, in 1757, Captain Galiot of Saint Malo negotiated a truce with the southern Labrador Inuit at Chateau Bay, the parties agreeing to trade at Quirpon (Martijn 2009: 79; Thévenard 1800). Franco-Inuit trade flourished for a few years there, much to the irritation of the British naval officers who now patrolled the coast (Graves 1762). At times, Inuit trading parties still resorted to what Europeans regarded as pilfering, but they had abandoned open warfare.

\section{A wider context}

To better understand Franco-Inuit relations in southern Labrador, it may be worth considering the wider context. The 17th-century French literary public learned of the Inuit but indirectly, through Danish impressions of Greenland, collected and 
rationalized by the diplomat and man of letters Isaac Lapeyrère in his Relation $d u$ Groenland of 1663. In this fascinating work, Lapeyrère (2014[1663]) accomplishes a number of things, including a clarification of outstanding contemporary questions about Arctic geography and a secure identification of the narwhal as the actual source of unicorn horns. More to the point here, he summarizes the ethnohistorical speculations of Scandinavian intellectuals like Ole Worm, about the Aboriginal people of Greenland. On linguistic grounds, Lapeyrère concludes that they could not be the descendants of the medieval Norse but were more likely of Asiatic origin. Lapeyrère makes no connection at all, however, with the Inuit of Labrador, with whom many of his fellow countrymen were so involved in that period. This suggests the intellectual distance in 17th-century France between mariners, merchants, and even commissaires de la Marine, on the one hand, and intellectuals like Lapeyrère, on the other. It may also suggest that the fishing crews who confronted mobile Inuit parties along the coasts of the Petit Nord did not recognize or at least did not report a significant ethnic distinction between the Inuit and the other Aboriginal peoples they encountered in the region, whether Mi'kmaq, Beothuk, or Innu-Montagnais, other than making the common observation that the Inuit were more difficult to deal with.

In general, tensions in southern Labrador might be better described as a Euro-Inuit issue rather than as a Franco-Inuit one. French records recount Inuit conflict with the Basques as well as with the Bretons and Normans. The experience of John Davis' crew in 1586 indicates that the English had not managed to avoid violence. In the 17th century, the Dutch developed an offshore whaling industry in the Davis Strait, and the first half of the 18th century saw serious efforts by Dutch interests to improve whaling profits by trading with the Inuit. It is hard to determine when the Dutch began to land and trade, although the death of a ship's carpenter at the hands of the Inuit in 1685 suggests both that this commerce may have a deep history and that it was, at least in the 17 th century, potentially as violent for the Dutch as it often was for the French (Kupp and Hart 1976).

A late 17th-century naval expedition brought the French into contact with the Inuit near Digges Islands (northwest of Nunavik) in the Arctic. An early note on an undated memoir of the Pélican's voyage from Plaisance to Hudson Strait in 1697 recommends the document "because of the description of this strait, of the islands there, of the dangers of ice and polar bears and, finally, because of the Esquimaux savages, with whom we dealt in an easy way" (Anonymous n.d.[ca. 1697]). The author of the memoir is most likely Claude-Charles Le Roy de La Potherie (dit Bacqueville de La Potherie, 1663-1736) who was on the expedition (Pouliot 2003) and published the same text in 1722 as part of his Histoire de l'Amérique Septentrionale. ${ }^{12}$ In it, and despite the "easy" dealings mentioned in the memoir, he describes the Inuit as "a very cruel nation with which no one until now has ever had commerce" (Bacqueville de La Potherie 1722: 75). He also tells us that Jean-Baptiste Le Moyne de Martigny took an armed squad of four or five men for a guarded, uneasy, but peaceful exchange with an Inuit party. The

12 I am indebted to Murielle Nagy for identifying Bacqueville de La Potherie as the likely author of the manuscript. 
Inuit, we learn, hunt whale and caribou with iron weapons and have caribou and polar bear skins to trade. Martigny warmed things up by passing around a pipe filled with tobacco. Communication was possible with at least one of the Inuit in French or possibly a trade pidgin, for the memoirist reports "I do not believe that there is any people who speak so fast. He had a Basque accent, not showing his teeth at all and articulating very distinctly" (ibid.: 78). When a young Inuit man joined the party, the author is given to reflections that were notably more humane than the attitudes of Champlain and European travellers of previous generations: "The arrival of these two Eskimos gave me the occasion for several reflections. There was one young man of 22 or 23 , very handsome. He had a completely happy physiognomy, an air of innocence seemed to be painted on his face - representing to me the pure state of nature in which men lived with [...] purity of heart [...]" (ibid.: 82).

This early romantic humanism could be taken to flag the beginnings of a shift in European or at least French attitudes to the Inuit. If so, this was surely a shift limited to intellectual elites and slow to affect the attitudes of merchants and fishermen. Parallel inconsistencies characterized British attitudes to the Beothuk in the early 19th century, when the optimistic paternalism of the Beothuck Institution in St. John's had less effect on Aboriginal-settler interaction than the bottom-line interests of furriers and salmon fishermen around the bays of Newfoundland's northeast coast (Howley 1915: 189216). If Euro-Inuit tensions in Labrador eventually eased, this probably had much to do with changing Inuit attitudes, when a century and a half of guerrilla war began to eat away at the gender balance within the limited Inuit population of southern Labrador (Mitchell 2013).

\section{Conclusion}

In summary, Europeans appear to have avoided the coast of Labrador through much of the 17th century, until the 1680s. This absence largely coincided with a longrunning guerrilla war, waged by the Inuit against the Breton fishers who exploited Newfoundland's Petit Nord and with the Basques who were beginning to exploit the west coast of the island. This context of conflict suggests that the movement of Inuit into southern Labrador by the late 16th century motivated European fishers to avoid the Labrador coast through much of the 17 th. It is hard to say whether this was the strategic intent of the Inuit when they planned their expeditions or whether it was simply a collateral consequence of their economic tactics of scavenging and raiding for iron. Perhaps it was both? If the Inuit were able to control the southern Labrador coast for most of a century and to slow the appropriation of that coast by Europeans for at least a century and a half, this was surely because they knew the territory and the adjacent part of Newfoundland well enough to effect concentrated attacks on dispersed boat crews. The French had better weaponry, but this technological advantage did not extend to the crews of their three-man fishing boats, who were often isolated and normally unarmed. The incident at Boutitou in 1693 makes it clear how a band of Inuit could even defeat French military patrols, by using the classic guerrilla tactic of sudden attack on a 
relatively small party (in this case two pataches) with limited but decisively superior forces (two shallops and six kayaks).

Making the point that the early Labrador Inuit regularly inflicted deadly force on others might be misunderstood as either the premise or conclusion of an ethnic bias. In fact, it simply recognizes that early modern Europeans did not have a monopoly either on martial attitudes nor on tactical abilities. Chronologies of European activity in Atlantic Canada in the early modern period sometimes emphasize infra-European tensions (e.g., Loewen and Delmas 2011, 2012). To pay serious attention to the prolonged Euro-Inuit conflict that flared on the Petit Nord for over 150 years offers a complementary perspective. It is also, at least minimal recognition of the Labrador Inuit as agents in their own historical drama. These ethnic conflicts did not really end until the establishment of a Moravian mission in northern Labrador, following the fall of New France in 1763 and the assertion of British sovereignty on the coast by the Royal Navy (Mitchell 2013).

\section{Acknowledgements}

The author acknowledges with thanks the support of the Social Sciences and Humanities Research Council of Canada and of Memorial University for the project $A n$ Archaeology of the Petit Nord. The author also thanks Greg Mitchell for discussions about Inuit agency and participants to the session on the Labrador coast at the meeting of the Society for Historical Archaeology held in Quebec City in 2014 and the anonymous reviewers for their comments. If the paper remains politically incorrect, it is my responsibility not theirs.

\section{Archival sources}

ANONYMOUS [probably Claude-Charles Le Roy Bacqueville de La Potherie]

n.d.[ca. 1697] Detroit de la Baye d'Hudson, manuscript, Aix-en-Provence, Archives nationales d'outre-mer, 3DFC/6/80 f. 34-46v.

\section{GRAVES, Thomas}

1762 Letter to the Commissioners of Trade and Plantations, 29 November 1762, UK National Archives, CO 194/15, ff. 45-46v, microfilm on file, St. John's, Memorial University of Newfoundland, Centre for Newfoundland Studies.

\section{HURIAU, Thomas}

1687 Rapport de capitaine, November 1687, Rennes, Archives départementales d'Ille-et-Vilaine, Amirauté de Saint Malo, 9B.196, 48. 
KIRKE, David

1639 Letter to Archbishop Laud, 2 October 1639, UK National Archives, CO 1/10 (40), 119, photocopy on file, St. John's, Memorial University of Newfoundland, Maritime History Archive.

NARP, Philibert de

1669 Memoire agnaux 1669 Terre Neuve mine de plomb, Aix-en-Provence, Archives nationales d'outre-mer, AC, $\mathrm{C}^{11} \mathrm{C}$ vol. 1, f. 29-30, Ottawa, Library and Archives Canada, microfilm 498.

LOUIS XV [of France]

1734 Ordonnance du Roy, 16 February 1734, Aix-en-Provence, Archives nationales d'outre-mer, F/3/54, f. 459-460.

\section{PARLEMENT DE BRETAGNE}

1640 Arrest de la Cour de Parlement de Bretagne... sur les règlemens du navires et gallays aux partyes de Terre Neuve, 31 March 1640, France, Archives de Colonies, $\mathrm{F}^{3}$, vol. 54, 248-51v, Ottawa, Library and Archives Canada, microfilm 564 .

\section{References}

BACQUEVILLE DE LA POTHERIE, Claude-Charles Le Roy

1722 Histoire de l'Amérique septentrionale, tome 1, Paris, Jean-Luc Nion and François Didot.

BAKKER, Peter

1989 "The language of the coast tribes is half Basque": A Basque-American Indian pidgin in use between Europeans and Native Americans in North America, ca. 1540-ca. 1640, Anthropological Linguistics, 31(3-4): 117-147.

1991 Trade Languages in the Strait of Belle Isle, Journal of the Atlantic Provinces Linguistic Association, 13: 1-20.

BARKHAM, Selma

1980 A note on the Strait of Belle Isle during the period of Basque contact with Indians and Inuit, Études/Inuit/Studies, 4(1-2): 51-58.

1982 The documentary evidence for Basque whaling ships in the Strait of Belle Isle, in G.M. Story (ed.), Early European Settlement and Exploitation in Atlantic Canada, St. John's, Memorial University of Newfoundland: 53-96.

1989 The Basque Coast of Newfoundland, Plum Point, Great Northern Peninsula Development Corporation. 
BIARD, Pierre

1616 Relation de la Nouvelle France, de ses terres, naturel du païs, \& de ses habitans..., Lyon, Louys Muguet.

BRIÈRE, Jean-François

1990 La pêche française en Amérique du Nord au XVIIIe siècle, Quebec City, Éditions Fides.

BROUAGUE, François Martel de

1923[1720] Mémoire de M. de Brouage, commandant pour le Roi à la côte de Labrador, au Conseil de Marine sur ce qui s'est passé à la côte de Labrador depuis le départ des derniers vaisseaux de l'année dernière 1719 (27 août 1720), in Pierre-George Roy (ed.), Rapport de l'Archiviste de la province de Québec pour 1922-1923, Quebec City, Ls-A. Proulx: 368.

1923[1729] Mémoire de M. de Brouage, commandant pour le Roi à la côte de Labrador, au Conseil de Marine sur ce qui s'est passé à la côte de Labrador depuis le départ des derniers vaisseaux de l'année 1728 (20 septembre 1729), in Pierre-George Roy (ed.), Rapport de l'Archiviste de la province de Québec pour 1922-1923, Quebec City, Ls-A. Proulx: 384.

CHAMPLAIN, Samuel de

1933[1632] Les voyages du Sieur de Champlain, part 2, book 3, in H.P. Biggar (ed.) and W.D. LeSueur (trans.), The Works of Samuel de Champlain, bilingual edition, vol. 5, Toronto, Champlain Society and University of Toronto Press (1971 reprint).

COOK, Ramsey (ed.)

1993 The Voyages of Jacques Cartier, H.P. Biggar (trans.), Toronto, University of Toronto Press.

COURTEMANCHE, Augustin Le Gardeur de

1927[c. 1705] Mémoire de voyage... à la côte des Esquimaux, in Privy Council (Great Britain), In the Matter of the Boundary between the Dominion of Canada and the Colony of Newfoundland in the Labrador Peninsula..., London, William Clowes and Sons, vol. 7: 3683-3689.

CROMPTON, Amanda

2014 The Many Habitations of Pierre Constantin: Exploring the History of French Residence in Southern Labrador in the Early- to Mid-Eighteenth Century, in John C. Kennedy (ed.), History and Renaissance of Labrador's Inuit Métis, St. John's, Memorial University of Newfoundland, ISER Books: 94-119.

\section{DU BOIS SAINT-SÉVERIN, Félix}

1877 Le vaisseau de guerre des pêcheurs malouins aux Terres Neuves, Revue de Bretagne et du Vendée, 42: 385-392, 467-475. 
FITZHUGH, William W., Anja HERZOG, Sophia PERDIKARIS and Brenda McLEOD

2012 Ship to Shore: Inuit, Early Europeans, and Maritime Landscapes in the Northern Gulf of St. Lawrence, in Ben Ford (ed.), The Archaeology of Maritime Landscapes, New York, Springer: 99-128.

GRAYDON, John

1910[1701] Answer to the Heads of Enquiries, 20 September 1701, in Cecil Headlam (ed.), Calendar of State Papers Colonial, America and West Indies, vol. 19, 1701, London, His Majesty's Stationery Office: 532.

HAKLUYT, Richard

1935[1584] Discourse on Western Planting, in E.G.R. Taylor (ed.) The Original Writings and Correspondence of the Two Richard Hakluyts, London, Hakluyt Society, vol. 2: 211-327.

HILLER, James K.

1996 The Newfoundland Fisheries Issue in Anglo-French treaties, 1712-1904, Journal of Imperial and Commonwealth History, 24(1): 1-23.

HOYARSABAL, Martin

1579 Les voyages avantureux du capitaine Martin de Hoyarsabal, habitant de Çubiburu, contentenant les reigles \& enseignments necessaires à la bonne $\&$ seure navigation, Bordeaux, Jean Chouin, photocopy on file, St. John's, Memorial University of Newfoundland, Centre for Newfoundland Studies.

JANES, John

1979[c. 1586] Narrative of the first Northwest Passage Voyage of John Davis, in David B. Quinn (ed.), New American World, vol. 4, Newfoundland from Fishery to Colony. Northwest Passage Searches, New York, Arno Press and Hector Bye: 233-238.

JOLLIET, Louis

1944[1694] Journal de Louis Jolliet allant à la descouverte de Labrador (1694), Jean Delanglez (ed.), in Antoine Roy (ed.), Rapport de l'Archiviste de la Province de Québec pour 1943-1944, Quebec City, Rédempti Paradis: 147206.

KAPLAN, Susan A.

1985 European Goods and Socio-Economic Change in Early Labrador Inuit Society, in William W. Fitzhugh (ed.), Cultures in Contact, the Impact of European Contacts on Native American Cultural Institutions A.D. 10001800, Washington, Smithsonian Institution: 45-69. 
KUPP, Jan and Simon HART

1976 The Dutch in the Strait of Davis and Labrador during the 17th and 18th Centuries, Man in the Northeast, 11: 3-20.

LAHONTAN, Louis Armand, baron de

1990[1703] Voyages du Baron de La Hontan dans l'Amérique septentrionale, in Réal Ouellet and Alain Beaulieu (eds), Oeuvres complètes, 2 volumes, Montréal, Presses de l'Université de Montréal.

LA MORANDIÈRE, Charles de

1962 Histoire de la pêche française de la morue dans l'Amérique septentrionale (des origines à 1789), 2 volumes, Paris, G-P. Maisonneuve et Larose.

\section{LANTEIGNE, Robert}

2014 Le mythe Thévenard et les conflits entre pêcheurs malouins et les Inuit au Petit Nord de 1749 à 1765, Le Manuscrit, Revue étudiante du Département d'Histoire de l'UQAM: Conflit, espace et religion, automne 2014 (online at: http://www.revuelemanuscrit.uqam.ca/).

LAPEYRÈRE, Isaac de

2014[1663] Relation du Groenland, in Fabienne Queyroux (ed.) Le Groenland retrouvé: La relation $d u$ Groenland d'Isaac Lapeyrère, Toulouse, Anacharsis Éditions.

LA RONCIÈRE, Charles de

1904 Le premier routier-pilote de Terre-Neuve (1579), Bibliothèque de l'École des Chartes, 65(1): 116-125.

LE CLERCQ, Chrestien

1999[1691] Nouvelle relation de la Gaspésie, Réal Ouellet (ed.), Montreal, Presses de l’Université de Montréal.

LESCARBOT, Marc

1907[1618] The History of New France, W.L. Grant (trans. and ed.), vol. 1, Toronto, Champlain Society.

LOEWEN, Brad and Vincent DELMAS

2011 Les occupations basques dans le Golfe du Saint-Laurent, 1530-1760. Périodisation, répartition géographique et culture matérielle, Archéologiques, 24: 23-55.

2012 The Basques in the Gulf of St. Lawrence and Adjacent Shores, Canadian Journal of Archaeology, 36(2): 213-266. 


\section{MANNION, John and Selma BARKHAM}

1988 The 16th Century Fishery, in R. Cole Harris and Geoffrey J. Matthews (eds), Historical Atlas of Canada, vol. 1, From the Beginnings to 1800, Toronto, University of Toronto Press: plate 22.

MARTIJN, Charles A.

1980 La présence Inuit sur la côte nord du Golfe St-Laurent à l'époque historique, Études/Inuit/Studies, 4(1-2): 105-125.

2009 Historic Inuit Presence in Northern Newfoundland circa A.D. 1550-1800, in David Keenlyside (ed.), Papers in Honour of James V. Wright, Gatineau, Canadian Museum of Civilization: 65-99.

MARTIJN, Charles A. and Louis-Jacques DORAIS

2001 Eighteenth-Century Innu (Montagnais) and Inuit Toponyms in the Northern Peninsula of Newfoundland, Newfoundland Studies, 17(2): 319-330.

McGHEE, Robert

2000 Radiocarbon Dating and the Timing of the Thule Migration, in Martin Appelt, Joel Berglund and Hans Christian Gulløv (eds), Identities and Cultural Contacts in the Arctic, Copenhagen, Danish National Museum and Danish Polar Centre: 75-89.

2009 When and Why Did the Inuit Move to the Eastern Arctic?, in Herbert Maschner, Owen Mason and Robert McGhee (eds), The Northern World, $A D$ 900-1400, Salt Lake City, University of Utah Press: 75-89.

\section{MITCHELL, Greg}

2013 The Inuit of Southern Labrador and their Conflicts with Europeans, to 1767, in Peter E. Pope and Shannon Lewis-Simpson (eds), Exploring Atlantic Transitions: Archaeologies of Transience and Permanence in New Found Lands, Woodbridge, Boydell Press, Society for Post-medieval Archaeology, Monograph 8: 320-330.

\section{PASTORE, Ralph T.}

1987 Fishermen, Furriers, and Beothuks: The Economy of Extinction, Man in the Northeast, 33: 47-62.

POPE, Peter E.

1995 The Practice of Portage in the Early Modern North Atlantic: Introduction to an Issue in Maritime Historical Anthropology, Journal of the Canadian Historical Association, 6: 19-41.

2000 Discovery and Memory: Zuan Caboto and the Norse in Newfoundland, in Anna Agnarsdóttir (ed.), Voyages and Exploration in the North Atlantic 
from the Middle Ages to the XVIIth Century, Reykjavík, University of Iceland Press: 45-60.

2009 Transformation of the Maritime Cultural Landscape of Atlantic Canada by Migratory European Fishers, 1500-1800, in Louis Sicking and Darlene Abreu-Ferreira (eds), Beyond the Catch: Fisheries of the North Atlantic, the North Sea and the Baltic, 900-1850, The Hague, Brill: 123-154.

2015a The Admiral System as Conflict Management, in the Transatlantic Migratory Fisheries, 1500-1800, in Robb Robinson, Martin Wilcox and Matthew McCarthy (eds), Human and Environmental Interactions in the Development of the North Atlantic Fisheries, North Atlantic Fisheries History Association, Studia Atlantica, 9: 23-46.

2015b The Champ Paya Fishing Room on Newfoundland's Petit Nord and the Maritime Cultural Landscape of the French Shore Fishery, 1504-1904, in Scott Jameison, Anne Pelta and Anna Thareau (eds), The French Presence in Newfoundland and Labrador: Past, Present, and Future, St. John's, Newfoundland and Labrador Studies, occasional publication, 3: 113-139.

2015c Mining Prospects, c. 1668, at a Prehistoric Soapstone Quarry in Fleur de Lys, Newfoundland, Newfoundland and Labrador Studies, 30(1): 139-151.

POULIOT, Léon

2003 Le Roy de La Potherie, Bacqueville de La Potherie, Claude-Charles in Dictionary of Canadian Biography, vol. 2, University of Toronto/Université Laval (online at: http://www.biographi.ca/en/bio/le_roy_de_la_potherie_ claude_charles_2F.html).

PROULX, Jean-Pierre

2007 The Presence of Basques in Labrador in the 16th Century, in Robert Grenier, Marc-André Bernier and Willis Stevens (eds), The Underwater Archaeology of Red Bay: Basque Shipbuilding and Whaling in the 16th Century, vol. 2, Material Culture, Ottawa, Parks Canada: 25-41.

\section{RAMSDEN, Peter and Lisa K. RANKIN}

2013 Thule Radiocarbon Chronology and Its Implications for Early InuitEuropean Interaction in Labrador, in Peter E. Pope and Shannon LewisSimpson (eds), Exploring Atlantic Transitions: Archaeologies of Transience and Permanence in New Found Lands, Woodbridge, Boydell Press, Society for Post-medieval Archaeology, Monograph 8: 299-309.

RANKIN, Lisa K.

2008 Native Peoples from the Ice Age to the Extinction of the Beothuk, in Newfoundland Historical Society, A Short History of Newfoundland and Labrador, Portugal Cove-St Phillip's, Boulder: 1-22. 
STEVENS, Willis, Daniel LAROCHE, Douglas BRYCE and R. James RINGER

2007 Evidence of Shipboard Activities, in Robert Grenier, Marc-André Bernier and Willis Stevens (eds), The Underwater Archaeology of Red Bay: Basque Shipbuilding and Whaling in the 16th Century, vol. 4, The 24M Hull, Ottawa, Parks Canada: 123-167.

STOPP, Marianne P.

2002 Reconsidering Inuit Presence in Southern Labrador, Etudes/Inuit/Studies, 26(2): 71-106.

STURTEVANT, W.C.

1980 The First Inuit Depiction by Europeans, Études/Inuit/Studies, 4(1-2): 47-50.

TAPPER, Bryn

2014 An Archaeological Analysis of the Distribution of French Fishing Rooms on the Petit Nord, Newfoundland, M.A. thesis, Memorial University of Newfoundland, St. John's.

TAYLOR, J. Garth

1980 The Inuit of Southern Quebec-Labrador, Études/Inuit/Studies, 4(1-2): 185193.

THÉVENARD, Antoine

1800 Sur les noms de différens lieux des côtes de Terre-Neuve et de Labrador, in Antoine Thévenard, Mémoires relatifs à la Marine, vol. 3, Paris, Laurens je.: 147-183.

TRUDEL, François

1978 Les Inuit du Labrador méridional face à l'exploitation canadienne et française des pêcheries (1700-1760), Revue d'Histoire de l'Amérique française, 31(4): 481-499.

1980 Les relations entre les Français et les Inuit au Labrador méridional, 16601760, Études/Inuit/Studies, 4(1-2): 135-146.

TUCK, James A.

1989 Excavations at Red Bay, Labrador - 1986, in Jane Sproull Thomson and Callum Thomson (eds), Archaeology in Newfoundland and Labrador 1986, St. John's, Newfoundland Museum, Historic Resources Division, Annual Report, 7: 213-237.

TURGEON, Laurier

1997 Bordeaux and the Newfoundland Trade during the Sixteenth Century, International Journal of Maritime History, 9(2): 1-28. 
1998 French Fishers, Fur Traders, and Amerindians during the Sixteenth Century: History and Archaeology, William and Mary Quarterly, 55(4): 585-610.

WALLACE, Birgitta Linderoth

2009 L'Anse aux Meadows, Leif Eriksson's Home in Vinland, Journal of the North Atlantic, special volume 2, Norse Greenland, Selected Papers from the Hvalsey Conference 2008: 114-125.

WOLFE, Kara

2013 Culture Contact in Southern Labrador and Newfoundland's Great Northern Peninsula: An Ethnohistorical and Archaeological Approach, M.A. thesis, Memorial University of Newfoundland, St. John's. 